\title{
The tissue renin-angiotensin system in human pancreas
}

\author{
M Tahmasebi ${ }^{1}$, J R Puddefoot ${ }^{1}$, E R Inwang ${ }^{\mathbf{2}}$ and G P Vinson ${ }^{\mathbf{1}}$ \\ ${ }^{1}$ Division of Biomedical Sciences, Queen Mary \& Westfield College, Mile End Road, London E1 4NS, UK \\ ${ }^{2}$ Breast Unit, Royal Hospitals Trust, London E1 1BB, UK \\ (Requests for offprints should be addressed to G P Vinson, Department of Biochemistry, Queen Mary \& Westfield College, Mile End Road, London E1 4NS)
}

\begin{abstract}
Evidence exists for the presence of a discrete tissue renin-angiotensin system (RAS) in mouse and rat pancreas that is thought largely to be associated with the vasculature. To investigate this in the human pancreas, and to establish whether the cellular sites of RAS components include the islets of Langerhans, we used immunocytochemistry to localise the expression of angiotensin II (AT1) receptors and (pro)renin, and non-isotopic in situ hybridisation to localise transcription of the (pro)renin gene. Identification of cell types in the islets of Langerhans was achieved using antibodies to glucagon and insulin.

The results show the presence of the AT1 receptor and (pro)renin both in the beta cells of the islets of Langerhans,
\end{abstract}

and in endothelial cells of the pancreatic vasculature. Transcription of (pro)renin mRNA, however, was confined to connective tissue surrounding the blood vessels and in reticular fibres within the islets. These findings are similar to those obtained in other tissues, and suggest that renin may be released from its sites of synthesis and taken up by possible cellular sites of action.

The results presented here suggest that a tissue RAS may be present in human pancreas and that it may directly affect beta cell function as well as pancreatic blood flow.

Journal of Endocrinology (1999) 161, 317-322

\section{Introduction}

The renin-angiotensin system (RAS) has important roles in the vascular system, and its principal hormonal product, angiotensin II (Ang II), is involved in regulation of blood pressure and aldosterone secretion, as well as sodium and potassium homeostasis (Peach 1977). In addition, localised tissue RASs have been described that either potentiate these systemic functions or have entirely separate activities, in the adrenal, uterus (Capponi et al. 1980, Wang et al. 1992, Whitebread et al. 1989), gonads (Vinson et al. 1997), heart (Phillips et al. 1993), kidney (Okura et al. 1992), brain and pituitary (Mendelssohn et al. 1984, Trolliet et al. 1992), and in our own studies, the use of a specific monoclonal antibody to the Ang II AT1 receptor has shown that it can be localised by immunocytochemistry in many different tissues (Barker et al. 1993b, Vinson et al. 1995a). In the pancreas, recent studies have suggested that the RAS is important in the regulation of islet blood flow (and thus, indirectly, insulin release) in the rat and mouse (Carlsson et al. 1998), and of anion secretion in the mouse exocrine pancreas (Leung et al. 1998). Additionally, angiotensin converting enzyme inhibition modulates mitosis in pancreatic cancer cells, and in human mammary ductal carcinoma cells (Redpy et al. 1995, Small et al. 1994). Since Ang II and the tissue RASs appear to play both autocrine and paracrine roles in other tissues
(Small et al. 1994, Vinson et al. 1995a, 1997), it was thought important to assess this possibility in the human pancreas.

This paper describes the use of immunohistochemical and in situ hybridisation techniques to localise AT1 receptors and sites for (pro)renin production in the human pancreas.

\section{Materials and Methods}

\section{Tissue collection}

The sections of human pancreas were generously provided by Drs C Brown and C Nichols, Department of Morbid Anatomy, Royal Hospitals Trust, London, E1 1BB. These were post mortem specimens usually taken, after cold storage, within hours of decease. Tissues were in good condition, and showed no signs of autolysis.

\section{Immunocytochemistry}

Primary antibodies used were: for the AT1 receptor, mouse monoclonal antibody 6313/G2 (Barker et al. 1993b), for renin and for (pro)renin, monoclonal antibody 2D12, a generous gift from Professor Pierre Corvol (Collège de France). 
Monoclonal antibodies against glucagon and insulin were obtained from the Sigma Chemical Co., (Poole, Dorset, UK).

Sections $(8 \mu \mathrm{m})$ were dehydrated, incubated in $3 \%$ hydrogen peroxide in methanol $(\mathrm{v} / \mathrm{v})$ for $15 \mathrm{~min}$, boiled for $16 \mathrm{~min}$ in $10 \mathrm{mmol} / 1$ citrate buffer, and washed in Tris buffered saline (TBS, pH 7·6, $50 \mathrm{mmol}$ Tris/1, $150 \mathrm{mmol}$ $\mathrm{NaCl} / 1,2 \mathrm{mmol} \mathrm{MgCl}_{2} / \mathrm{l}$ ). To block non-specific binding, sections were first incubated for $20 \mathrm{~min}$ with normal rabbit serum (Sigma, 1:5 dilution) in TBS before incubation (60 min for $6313 / \mathrm{G} 2,30 \mathrm{~min}$ for 2D12) with primary antibody (for 6313/G2: neat hybridoma supernatant, RPMI 1640 culture medium (ICN-Flow Ltd, High Wycombe, Bucks., UK), for 2D12: diluted 1000fold in TBS). Sections were then washed twice and left to soak in TBS $(5 \mathrm{~min})$. Sections were then exposed to biotinylated rabbit anti mouse IgG complex (Dako Ltd, High Wycombe, Bucks, UK), diluted 1:400 in TBS (30 min), washed in TBS then incubated for $30 \mathrm{~min}$ with avidin-biotin complex (Dako), and washed again in TBS. Visualisation of receptor was achieved through the diaminobenzidine hydrochloride (DAB)-hydrogen peroxide chromogen substrate reaction (Sigma) using $0.6 \mathrm{mg} \mathrm{DAB}$ and $1.6 \mathrm{mg}$ hydrogen peroxide per $\mathrm{ml}$ in TBS $(0.05 \mathrm{~mol} / 1$ for $10 \mathrm{~min})$. Slides were washed in water (10 min), counterstained in Gills haematoxylin ( $2 \mathrm{~min})$, re-washed in water $(5 \mathrm{~min})$, differentiated briefly in acid alcohol $(10 \mathrm{ml}$ of $1 \% \mathrm{HCl}$ in $990 \mathrm{ml}$ of $70 \%$ industrial methylated spirit (IMS), BDH Lab. supplies, Poole, Dorset, UK), dehydrated in IMS, cleared with xylene twice and mounted in Depex mounting medium (BDH Ltd, Poole, Dorset, UK).

As a further control for AT1 staining, sections were also treated with antibody previously saturated with the peptide antigen (Barker et al. 1993b). In addition, further sections were stained with another mouse monoclonal, IZAb, as primary antibody (Laird et al. 1988).

\section{In situ hybridisation}

Oligonucleotide probes, 45 bases comprising antisense (base pairs 187-142) and sense sequences (base pairs 142-187) were derived from the translated exon 2 of the human renin gene. Probes were enzymatically labelled with a digoxigenin (DIG)-labelled nucleotide tail with incorporation of several DIG-dUTP molecules at their $3^{\prime}$-end using terminal transferase (Boehringer Mannheim, Lewes, Sussex, UK).

The hybridised DIG-labelled probes were detected with high affinity alkaline phosphatase-conjugated sheep anti-DIG antibody (1:200 dilution in modified TBS). Pancreas tissue sections were post-fixed in $0.4 \%(\mathrm{w} / \mathrm{v})$ paraformaldehyde in PBS (pH 7·4, $20 \mathrm{mmol} \mathrm{NaH}_{2} \mathrm{PO}_{4} / 1$, $80 \mathrm{mmol} \mathrm{NaHPO} / 1$ and $100 \mathrm{mmol} \mathrm{NaCl} / \mathrm{l}$ ) for $15 \mathrm{~min}$. The sections were then incubated with $0 \cdot 25 \%$ acetic anhydride $(\mathrm{v} / \mathrm{v})$ in $0.1 \mathrm{~mol}$ triethanolamine/1 and $0.9 \%$ (w/v) $\mathrm{NaCl}$ solution and incubated for $10 \mathrm{~min}$, followed by washing in diethyl pyrocarbonate (DEPC) water. Sections were covered with hybridisation buffer $(\mathrm{pH} 7.5$, $10 \mathrm{mmol}$ Tris $/ \mathrm{l}), \quad 50 \% \quad(\mathrm{v} / \mathrm{v})$ formamide, $4 \times \mathrm{SSC}$ $(1 \times$ SSC contains $150 \mathrm{mmol}$ sodium chloride/l and $15 \mathrm{mmol}$ trisodium citrate/1), $1 \times$ Denhardt's solution, $500 \mu \mathrm{g}$ salmon sperm DNA $/ \mathrm{ml}$ (Sigma), 10\% (v/v) dextran sulphate containing DIG $3^{\prime}$-end labelled oligonucleotide probe to human renin, and incubated at $37^{\circ}$ overnight. The unhybridized probe was washed away with serial washing in $4 \times$ SSC, $2 \times$ SSC and $1 \times$ SSC $\left(35 \mathrm{~min}\right.$ at $37^{\circ}$ ) and for further $15 \mathrm{~min}$ in modified TBS

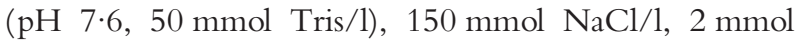
$\mathrm{MgCl}_{2} / 1$ and $0 \cdot 1 \%(\mathrm{w} / \mathrm{v})$ BSA with added $0 \cdot 1 \%(\mathrm{v} / \mathrm{v})$ Triton X-100 at room temperature. Sections were incubated with blocking reagent (Boehringer Mannheim) $1 \%(\mathrm{w} / \mathrm{v})$ for $10 \mathrm{~min}$, followed by incubation with alkaline phosphatase-conjugated sheep anti-DIG antibody (1:200 dilution) for $3 \mathrm{~h}$. Excess antibody was removed by washing with TBS (pH 9.5, $100 \mathrm{mmol}$ Tris/l and $100 \mathrm{mmol} \mathrm{NaCl} / \mathrm{l})$. The antibody was visualised using 5-bromo-4-chloro-3-indolyl phosphate (BCIP $165 \mu \mathrm{g}$ / $\mathrm{ml}$ ) and nitro blue tetrazolium salt (NBT $330 \mu \mathrm{g} / \mathrm{ml}$ ) for 2-20 $\mathrm{h}$ at room temperature. Levamisole $(0 \cdot 1 \mathrm{mmol} / \mathrm{l})$ was added to the substrate solution to reduce endogenous alkaline phosphatase activity. Finally, sections were washed in TE ( $\mathrm{pH} 7 \cdot 4,10 \mathrm{mmol}$ Tris/l, 1 mmol EDTA/l, Sigma) buffer for $30 \mathrm{~min}$ and mounted with Apathys mounting medium (Sigma).

\section{Results}

\section{Immunocytochemistry}

Positive staining for the AT1 receptor (antibody: 6313/ G2) was found in cells of the islets of Langerhans (Fig. 1A). These were distributed similarly to cells staining for insulin, but not for glucagon (not shown). Sections treated similarly, but using antibody presaturated with peptide antigen (or in the absence of primary antibody) showed no immunostaining (Fig. 1B). Additionally, sections using another primary antibody, IZAb, or from which primary antibody was omitted altogether, showed no staining (not illustrated). Further immunocytochemistry for (pro)renin (using antibody 2D12) also demonstrated positive staining in islets, with a distribution similar to that of the AT1 receptor (Fig. 1C), and also in endothelial cells of blood vessels within the gland (not shown). Controls from which the primary antibody was omitted showed no staining (Fig. 1D).

\section{In situ hybridisation}

Using the antisense hybridisation probe, messenger RNA coding for prorenin was seen in reticular fibres within the 
islets of Langerhans (Fig. 1E) and in fibroblasts surrounding the blood vessels (Fig. 1G). The sense probe controls showed no staining (Fig. 1F \& H).

\section{Discussion}

Interest in the relationship between the systemic RAS and endocrine pancreas function has largely been concerned with the role of Ang II in the the hypertension of diabetes, its complications such as nephropathy, and retinopathy, and their possible control by drugs regulating its action (Hsueh \& Anderson 1993, Vandyk et al. 1994, Tait \& Tait 1997, Goa 1997, Allen 1997, Anderson 1997, Kim et al. 1997, Chaturvedi et al. 1998). In addition, studies with experimental animals as well as patients have shown that the systemic RAS may be perturbed in diabetes, though the situation is complex, and opposing effects, for example on Ang II receptor function have been reported in different tissues (Sechi et al. 1994, Cheng et al. 1994, Fliser et al. 1997, Brown et al. 1997, Nakata et al. 1998). ACE inhibition may also affect the action of insulin, though this might be attributable to increased bradykinin (Carvalho et al. 1997).

The actions of anti-Ang II drugs, may not, however, always be at the level of the systemic RAS, and the local tissue RASs may also be involved, for example in the kidney (Anderson et al. 1997), or eye (Wagner et al. 1996). It is in this context that the possibility that the pancreas itself may contain a localised tissue RAS acquires a special interest. Clear evidence of this possibility was described in the canine pancreas, in which the presence of angiotensinogen mRNA and protein, Ang II, and both AT1 and AT2 receptors was demonstrated (Chappell et al. 1991, 1992). Autoradiography showed that receptors were present both in acinar and in islet cells (Chappell et al. 1992, 1995), though the AT2 subtype predominated.

Although a similar distribution of Ang II binding sites in both endocrine and acinar cells of the rat pancreas has been described in studies using ligand binding methods, other reports, in which polyclonal antibodies to peptides derived from the AT1 and AT2 receptor subtypes were used, suggest that the major site for Ang II binding in rat or mouse pancreas lies within the endothelial cells of the blood vessels, and the epithelia of the ductal system, in which Ang II was subsequently shown to stimulate anion secretion (Leung et al. 1997, Chan et al. 1997). However, only weak reactivity was seen in acinar cells, and none was reported for the endocrine pancreas (Leung et al. 1997). A similar distribution was also reported for Ang II itself (Leung, Chan \& Wong 1998). That Ang II may have a significant effect on pancreatic blood flow is clear, and indeed, in rats it appears to delay the response to glucose, perhaps mainly as a result of its vasocontrictive action (Carlsson, Berne \& Jansson 1998). The question of the presence of Ang II receptors in the endocrine pancreas, and its relationship to possible sites of endogenous Ang II production, however, requires resolution for species other than the dog, and has a clear relevance to our understanding of endocrine pancreas function in health and in disease.

It is important to emphasise that the monoclonal antibody against the AT1 receptor used in the present study is highly specific. Evidence includes the following: (1) Demonstration of immunoreactivity in Western blots from COS-7 cells transfected with cDNA coding for AT1, but not in untransfected cells (Barker et al. 1993a). (2) Demonstration of single immunoreactive bands corresponding in molecular weight to the AT1 receptor in western blots of membrane fractions from adrenals and other target tissues. Though some of these sites (e.g. sperm, fallopian tube, breast) had not previously been shown to possess AT1 receptors, the findings were substantiated either by ligand binding studies, or the demonstration of AT1 specific responses to Ang II (Vinson et al. 1995a,b, Saridogan et al. 1996a,b, Inwang et al. 1997). (3) Pre-saturation of antibody with the antigen eliminates immunostaining of immunopositive sections (HarrisonBernard et al. 1997). (4) In rat adrenal cells, incubation with antibody specifically inhibits receptor internalisation and Ang II-stimulated protein kinase C activation (Vinson et al. 1994, Kapas et al. 1994).

Within the limits of the material available to us, therefore, we believe that the results shown in Fig. 1A give good prima facie evidence that the human endocrine pancreas does indeed contain AT1 receptors and, from their distribution, these appear to be primarily located on beta cells. Acinar cells did not contain AT1 receptors, although in agreement with others they are certainly present in the endothelial cells of the blood vessels.

In other epithelial, or epithelioid, tissues in which we have similarly shown the presence of AT1 receptors, other data, obtained by immunocytochemistry or in situ hybridisation have also shown that specifically localised RASs may exist that deliver Ang II directly to its sites of action in a paracrine manner. This is certainly true, for example, in the rat adrenal, in which we and others have demonstrated the regulation of (pro)renin expression in a manner that suggests its key role in tissue modelling and the secretory response to systemic stimulation (Mulrow et al. 1996, Ho et al. 1998, Vinson et al. 1998). In the breast too, ductal epithelia are surrounded by fibroblasts and myoepithelial tissue that transcribe (pro)renin mRNA (Tahmasebi et al. 1998). This has parallels in the present study in which cells lying within the islets contain (pro)renin mRNA (Fig. 1E). However, use of a monoclonal antibody against (pro)renin shows that the protein occurs mostly in the beta cells themselves (Fig. 1C), raising the possibility that (pro)renin, synthesised in the reticular fibres within the islets, may be taken up by the pancreatic endocrine cells. Uptake of renin in target cells has been been suggested in other contexts (Sealey 1995, Sealey et al. 1996). 

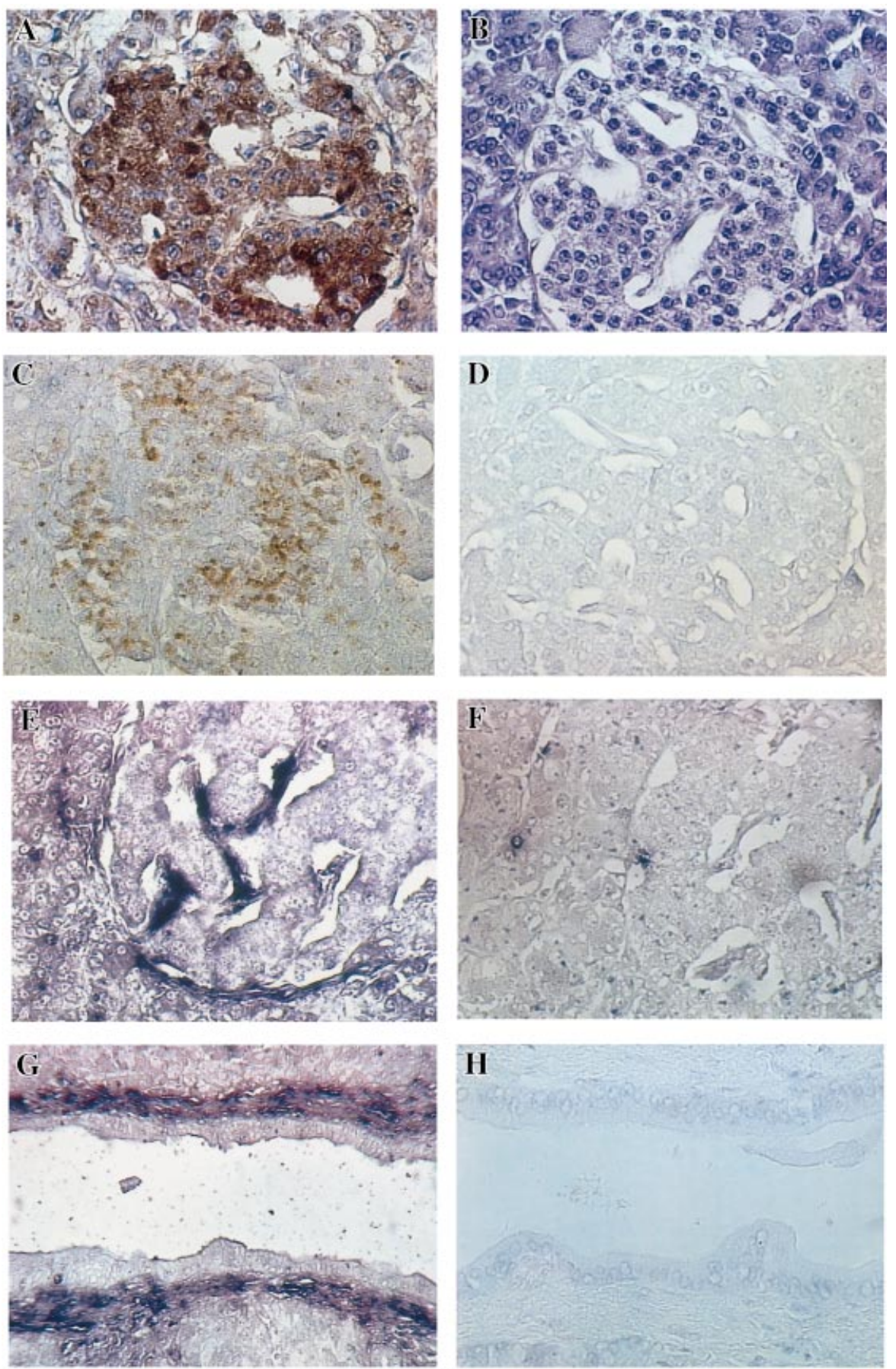

Figure 1 Immunocytochemistry shows the distribution of AT1 receptors (brown stain) in beta cells of the islets of Langerhans in human pancreas. It is absent from reticular fibres (A). Control sections, using antibody presaturated with peptide antigen, showed no staining (B). The distribution of renin (brown stain) is similarly confined to beta cells of the islets (C). Control sections again showed no immunoreactivity (D). In situ hybridisation shows that prorenin mRNA (dark stain) was transcribed in the reticular fibres of islets $(E)$ and the fibroblasts and connective tissue surrounding blood vessels (G). The negative controls, using sense probe, showed no staining $(\mathrm{F} \& \mathrm{H})$. Magnification $\times 166$ throughout. 
Ang II, it is becoming clear, has widely distributed functions in many different epithelia, or epithelial-derived cells, associated with a local RAS that presumably responds in a manner quite separate from that of the systemic RAS, and in accordance with specific tissue functions. The endocrine pancreas is no exception to this, and the results presented here clearly link the RAS with beta cell function, under normal conditions, and plausibly, in disease.

\section{References}

Allen TJ, Cao ZM, Youssef S, Hulthen UL \& Cooper ME 1997 Role of angiotensin II and bradykinin in experimental diabetic nephropathy - functional and structural studies. Diabetes $\mathbf{4 6}$ 1612-1618.

Anderson S 1997 Role of local and systemic angiotensin in diabetic renal disease. Kidney International S63 S107-S110.

Barker S, Marchant W, Clark AJL, Jimenez E, Marsigliante S, Montiel M \& Vinson GP 1993a Comparison of Cos cell transfected AT1A and AT1B angiotensin II receptors and angiotensin II receptor isoforms in rat tissues using isoelectric focusing. Biochemical and Biophysical Research Communications 192 392-398.

Barker S, Marchant W, Ho MM, Puddefoot JR, Hinson JP, Clark AJL \& Vinson GP $1993 b$ A monoclonal antibody to a conserved sequence in the extracellular domain recognises the angiotensin II AT1 receptor in mammalian tissues. Journal of Molecular Endocrinology 11 241-245.

Brown L, Wall D, Marchant C \& Sernia C 1997 Tissue-specific changes in angiotensin II receptors in streptozotocin-diabetic rats. Journal of Endocrinology 154 355-362.

Capponi AM \& Catt KJ 1980 Solubilisation and characterisation of adrenal and uterine angiotensin II receptors after photoaffinity labelling. Journal of Biological Chemistry 225 12081-12086.

Carlsson PO, Berne C \& Jansson L 1998 Angiotensin II and the endocrine pancreas: effects on islet blood flow and insulin secretion in rats. Diabetologia 41 127-133.

Carvalho CRO, Thirone ACP, Gontijo JAR, Velloso LA \& Saad MJA 1997 Effect of captopril, losartan, and bradykinin on early steps of insulin action. Diabetes 46 1950-1957.

Chan HC, Law SH, Leung PS, Fu LXM \& Wong PYD 1997 Angiotensin II receptor type I regulated anion secretion in cystic fibrosis pancreatic duct cells. Journal of Membrane Biology 156 241-249.

Chappell MC, Millsted A, Diz DI, Brosnihan KB \& Ferrario CM 1991 Evidence for an intrinsic angiotensin system in the canine pancreas. Journal of Hypertension 9 751-759.

Chappell MC, Diz DI \& Jacobsen DW 1992 Pharmacological characterisation of angiotensin-II binding-sites in the canine pancreas. Peptides 13 313-318.

Chappell MC, Jacobsen DW \& Tallant EA 1995 Characterization of angiotensin-II receptor subtypes in pancreatic acinar ar42j cells. Peptides 16 741-747.

Chaturvedi M, Sjolie AK, Stephenson JM, Abrahamian H, Keipes M, Castellarin A, Roguljapepeonik Z \& Fuller JH 1998 Effect of lisinopril on progression of retinopathy in normotensive people with type 1 diabetes. Lancet $35128-31$.

Cheng HF, Burns KD \& Harris RC 1994a Reduced proximal tubule angiotensin-II receptor expression in streptozotocin-induced diabetes-mellitus. Kidney International 46 1603-1610.

Fliser D, Keller C, Bahrmann P, Franek E, Schreckling H, Bergis K \& Ritz E 1997 Altered action of angiotensin II in patients with type 2 diabetes mellitus of recent onset. Journal of Hypertension $\mathbf{1 5}$ 293-299.
Goa KL, Haria M \& Wilde MI 1997 Lisinopril - a review of its pharmacology and use in the management of the complications of diabetes mellitus. Drugs 53 1081-1105.

Harrison-Bernard LM, Navar LG, Ho MM, Vinson GP \& El-Dahr SS 1997 Immunohistochemical localization of ang II AT (1) receptor in adult rat kidney using a monoclonal antibody. American Journal of Physiology 42 F170-F177.

Ho MM \& Vinson GP 1998 Transcription of (pro)renin mRNA in the rat adrenal cortex, and the effects of ACTH treatment and a low sodium diet. Journal of Endocrinology 157 217-223.

Hsueh WA \& Anderson PW 1993 Systemic hypertension and the renin-angiotensin system in diabetic vascular complications. American Journal of Cardiology $72 \mathrm{H} 14-\mathrm{H} 21$.

Inwang ER, Puddefoot JR, Brown CL, Goode AW, Marsigliante S, Ho MM, Payne JG \& Vinson GP 1997 Angiotensin II type 1 receptor expression in human breast tissues. British Journal of Cancer 75 1279-1283.

Kapas S, Hinson JP, Puddefoot JR, Ho MM \& Vinson GP 1994 Internalization of the type-I angiotensin-II receptor (AT1) is required for protein-kinase-C activation but not for inositol trisphosphate release in the angiotensin-II stimulated rat adrenal zona glomerulosa cell. Biochemical and Biophysical Research Communications 204 1292-1298.

Kim S, Wanibuchi H, Hamaguchi A, Miura K, Yamanaka S \& Iwao H 1997 Angiotensin blockade improves cardiac and renal complications of type II diabetic rats. Hypertension 30 1054-1061.

Laird SM, Vinson GP \& Whitehouse BJ 1988 Monoclonal antibodies against rat adrenocortical antigens. Acta Endocrinologica 119 420-426.

Leung PS, Chan HC, Fu LXM \& Wong PYD 1997 Localization of angiotensin II receptor subtypes AT (1) and AT(2) in the pancreas of rodents. Journal of Endocrinology 153 269-274.

Leung PS, Chan HC \& Wong PYD 1998 Immunohistochemical localisation of angiotensin II in the mouse pancreas. Histochemical Journal 30 21-25.

Mendelssohn FAD, Quritonm R, Saavedra JM, Aguilera G \& Catt KJ 1984 Autoradiographic localisation of angiotensin II receptor in rat brain. Proceedings of the National Academy of Sciences of the USA $\mathbf{8 1}$ 1575-1579.

Mulrow PJ \& Francosaenz R 1996 The adrenal renin-angiotensin system - a local hormonal regulator of aldosterone production. Journal of Hypertension 14 173-176.

Nakata T, Takeda K, Hatta T, Kiyama M, Moriguchi J, Miki S, Kawa T, Morimoto S, Nakamura K, Uchida A, Itoh H, Sasaki S \& Nakagawa M 1998 Blockade of angiotensin II receptors inhibits the increase in blood pressure induced by insulin. Journal of Cardiovascular Pharmacology 31 248-252.

Okura T, Kitami Y, Wakamiya R, Marumoto K, Iwata T \& Hiwada K 1992 Renal and extra renal gene expression in spontaneously hypertensive rats. Blood Pressure (suppl 1) 3 6-11.

Peach MT 1977 The renin angiotensin system. Physiological Reviews 57 313-370.

Phillips MI, Speakman EA \& Kimura B 1993 Levels of angiotensin and molecular biology of the tissue renin-angiotensin systems. Regulatory Peptide 43 1-20.

Redpy MK, Baskaran K \& Moiteni A 1995 Inhibitors of angiotensinconverting enzyme modulate mitosis and gene expression in pancreatic cancer cells. Society for Experimental Biology and Medicine $210221-226$.

Saridogan E, Djahanbakhch O, Puddefoot JR, Demetroulis C, Collingwood K, Mehta JG \& Vinson GP 1996a Angiotensin II receptors and angiotensin II stimulation of ciliary activity in human fallopian tube. Journal of Clinical Endocrinology Metabolism 81 2719-2725.

Saridogan E, Djahanbakhch O, Puddefoot JR, Demetroulis C, Dawda R, Hall AJ \& Vinson GP $1996 b$ Type 1 angiotensin II receptors in human endometrium. Molecular Human Reproduction 2 659-664.

Sealey JE 1995 Evidence for cardiovascular effects of prorenin. Journal of Human Hypertension 9 381-384. 
Sealey JE, Catanzaro DF, Lavin TN, Gahnem F, Pitarresi T, Hu LF \& Laragh JH 1996 Specific prorenin/renin binding (probp)identification and characterization of a novel membrane site. American Journal of Hypertension 9 491-502.

Sechi LA, Griffin CA \& Schambelan M 1994 The cardiac reninangiotensin system in stz-induced diabetes. Diabetes $\mathbf{4 3}$ $1180-1184$.

Small W, Ward WF, Kim YT, Molteni A \& Goolsby GL 1994 Captopril inhibits proliferation of human mammary ductal carcinoma cells in culture. FASEB Journal 8 A672.

Tahmasebi M, Puddefoot JR, Inwang ER, Goode AW, Carpenter R \& Vinson GP 1998 Transcription of prorenin gene in normal and diseased breast. European Journal of Cancer 34 1777-1782.

Tait JF \& Tait SAS 1997 Insulin, the renin-angiotensin-aldosterone system and blood pressure. Perspectives in Biology and Medicine $\mathbf{4 0}$ 246-259.

Trolliet MR \& Phillips MI 1992 The effect of chronic bilateral nephrectomy on plasma and brain angiotensin. Journal of Hypertension 10 29-36.

Vandyk DJ, Erman A, Erman T, Chengal B, Sulkes J \& Boner G 1994 Increased serum angiotensin-converting enzyme-activity in type-I insulin-dependent diabetes-mellitus - its relation to metabolic control and diabetic complications. European Journal of Clinical Investigation 24 463-467.

Vinson GP, Ho MM, Puddefoot JR, Teja R \& Barker S 1994 Internalisation of the type I angiotensin II receptor (AT1) and angiotensin II function in the rat adrenal zona glomerulosa cell. Journal of Endocrinology 141 R5-R9.
Vinson GP, Ho MM \& Puddefoot JR 1995a The distribution of angiotensin II type 1 receptors, and the tissue renin-angiotensin systems. Molecular Medicine Today 1 35-39.

Vinson GP, Puddefoot JR, Ho MM, Barker S, Mehta J, Saridogan E \& Djahanbakhch O $1995 b$ Type 1 angiotensin II (AT1) receptors in sperm. Journal of Endocrinology 144 369-378.

Vinson GP, Saridogan E, Puddefoot JR \& Djahanbakhch O 1997 Tissue renin-angiotensin systems and reproduction. Human Reproduction 12 651-662.

Vinson GP \& Ho MM 1998 The adrenal renin-angiotensin system in the rat. Hormone and Metabolic Research 30 355-359.

Wagner J, Danser AHJ, Derkx FHM, Dejong PTVM, Paul M, Mullins JJ, Schalekamp MADH \& Ganten D 1996 Demonstration of renin messenger-RNA, angiotensinogen messenger-RNA, and angiotensin-converting enzyme messenger-RNA expression in the human eye - evidence for an intracellular renin-angiotensin system. British Journal of Ophthalmology 80 159-163.

Wang Y, Yamaguchi T, Francosaenz R \& Mulrow PJ 1992 Regulation of renin gene expression in rat adrenal zona glomerulosa cells. Hypertension 20 776-781.

Whitebread S 1989 Preliminary biochemical characterisation of two angiotensin II receptor subtypes. Biochemical and Biophysical Research Communications 163 284-291.

Received 29 September 1998

Accepted 3 December 1998 